\title{
Editorial Book Review: János Tóth, Attila László Nagy, Dávid Papp: Reaction kinetics: exercises, programs and theorems. Mathematica for deterministic and stochastic kinetics
}

\author{
Springer, New York, 2018, ISBN 978-1-4939-8641-5
}

\section{Gábor Lente ${ }^{1}$}

Published online: 20 May 2020

(C) Akadémiai Kiadó, Budapest, Hungary 2020

The chemical kinetic analysis of complex reaction mechanism has played a very significant role in the life of both of this journal [1-8] and its current Editor-in-Chief [9-12]. Therefore, I am very happy to recommend a book to our readers that was recently published and provides much-needed help in acquiring up-to-date practical knowledge in the evaluation and mathematical description of kinetic data.

The senior author of the book, János Tóth from the Budapest University of Technology and Economics, is a mathematician who has worked in this field since the 1970s. He was the recipient of the lifetime achievement award during the Mathematics in (Bio)chemical Kinetics and Engineering conference in 2017 [13]. He has already published a much-cited book on chemical kinetics together with his personal friend and long-time scientific collaborator Péter Érdi [14]. For me, the most memorable early achievements of János include publishing the essence of the widely used stochastic Gillespie algorithm [15, 16] -2 years before Gillespie did [17]; and providing an early insight into the stochastic description of single enzyme catalysis [18]. János has also published quite a few papers in this journal and its predecessor $[5,15,16,19-24]$.

The co-authors of János Tóth in this book are much younger scientists. Dávid Papp is an assistant professor at the Department of Mathematics at North Carolina State University. Attila László Nagy is still working on his $\mathrm{PhD}$ thesis in mathematics, but in the meantime, he decided to follow the big money in the application of stochastic mathematics: he took a job at the Hungarian National Lottery Company.

As an experienced researcher in chemical kinetics, I am very much aware of the fact that kineticists are big-time end-users of mathematical methods. First of all, we often rely on solving ordinary differential equations for our evaluation, actually

Gábor Lente

reac@gamma.ttk.pte.hu

1 Editorial Office, Reaction Kinetics, Mechanisms and Catalysis, Department of General and Physical Chemistry, University of Pécs, Pécs, Hungary 
often very stiff ones. Then least squares fitting is typically our choice when we want to extract certain parameters from data. Last, but not least, even when we work with symbolic solutions, those can typically be found with computerized aid except for the simplest of cases. Fortunately, there are a number of softwares that are able to handle symbolic mathematics as well, Mathematica is a leading one among them. Its use is taught at universities, and this book seems to be a product of years of teaching, during which the authors have developed a Mathematica program package called ReactionKinetics, Version 1.0. They are happy to share this package with everyone who is interested.

The book is s sort of Mission Impossible without Tom Cruise: it tries to be useful for beginners in the field with some knowledge in introductory calculus, linear algebra, and stochastics, but also be handy as a reference book for experts. The success of this approach is remarkable. The authors compiled a lot of recently published information in a unified format, ready to be taught in a university course, but also directly applicable in research. It is quite different from the typical mathematical approach: a theorem is almost never proven here, only the reference for the relevant publication is given, the focus is on the applications. Without a deep knowledge of programming, the reader will be able to use up-to-date methods in chemical kinetics, which is a surprisingly rare skill today.

The book comprises 4 main parts with 14 individual chapters. The five chapters in Part I are dedicated to giving a general framework a chemical kinetics. Then in Part II, the continuous time continuous state deterministic model is discussed in detail. In the large majority of books on chemical kinetics, this is the only model considered even without pointing out its inherent limitations. Separate chapters deal with kinetic differential equations in general, the stationary points appearing in them, the time-dependent behavior of concentration (i.e. the solutions of the ordinary differential equations induced by a kinetic scheme), and finally the commonly used approximations in solving the differential equations. Part III, which contains a single chapter, focuses on the continuous time discrete state stochastic model, which is very close to my heart. This text is among the most authoritative ones that have ever been written for education purposes on this subject. Part IV is rich source of additional information on the mathematical background and also gives the solutions of problems used in the book.

Overall, I would like to recommend this book to everyone who works with chemical kinetics. I think even the experienced researchers will be surprised at the fact that how much they do not know about their own disciplines.

\section{References}

1. Mozgunov P, Beccuti M, Horvath A, Jaki T, Sirovich R, Bibbona E (2018) A review of the deterministic and diffusion approximations for stochastic chemical reaction networks. Reac Kinet Mech Catal 123:289-312

2. Milani G, Milani F (2018) Quasi-analytical kinetic model for natural rubber and polybutadiene rubber blends. Reac Kinet Mech Catal 123:351-365 
3. Lipták G, Hangos KM, Szederkenyi G (2018) Approximation of delayed chemical reaction networks. Reac Kinet Mech Catal 123:403-419

4. Salvestrini S (2018) Analysis of the Langmuir rate equation in its differential and integrated form for adsorption processes and a comparison with the pseudo first and pseudo second order models. Reac Kinet Mech Catal 123:455-472

5. Dukarić M, Errami H, Jerala R, Lebar T, Romanovski VG, Tóth J, Weber A (2019) On three genetic repressilator topologies. Reac Kinet Mech Catal 126:3-30

6. Čupić Ž, Ivanović-Šašić A (2019) Alternating catalytic reactions. Reac Kinet Mech Catal 126:577-586

7. Magyar A (2019) Generalized mass action realizations of temperature dependent chemical reaction networks. Reac Kinet Mech Catal 126:587-600

8. Čiegis R, Katauskis P, Skakauskas V (2019) Modelling competition of the enzyme-catalysed glucose oxidation and redox reactions in scanning electrochemical microscopy. Reac Kinet Mech Catal 127:543-559

9. Lente G, Espenson JH (2000) Kinetics and mechanism of oxygen transfer to methyl(oxo) dithiolatorhenium(V) complexes. Inorg Chem 39:4809-4814

10. Espenson JH, Shan X, Wang Y, Huang R, Lahti DW, Dixon JN, Lente G, Ellern A, Guzei I (2002) Synthesis and characterization of dimetallic oxorhenium(V) and dioxorhenium(VII) compounds, and a study of stoichiometric and catalytic reactions. Inorg Chem 41:2583-2591

11. Lente G (2007) The effect of parity violation on kinetic models of enantioselective autocatalyis. Phys Chem Chem Phys 9:6134-6141

12. Mazzei L, Cianci M, Musiani F, Lente G, Palombo M, Ciurli S (2017) Inactivation of urease by catechol: kinetics and structure. J Inorg Biochem 166:182-189

13. Lente G (2018) Mathematics in (bio)chemical kinetics 2017. Reac Kinet Mech Catal 123:287-288

14. Érdi P, Tóth J (1989) Mathematical models of chemical reactions. Theory and applications of deterministic and stochastic models. Manchester University Press/Princeton University Press, Princeton

15. Sipos T, Tóth J, Érdi P (1974) Stochastic simulation of complex chemical reactions by digital computer. I. The model. Reac Kinet Catal Lett 1:113-117

16. Sipos T, Tóth J, Érdi P (1974) Stochastic simulation of complex chemical reactions by digital computer. II. Applications. Reac Kinet Catal Lett 1:209-213

17. Gillespie DT (1976) A general method for numerically simulating the stochastic time evolution of coupled chemical reactions. J Comput Phys 22:403-434

18. Arányi P, Tóth J (1977) A full stochastic description of the Michaelis-Menten reaction for small systems. Act Biochim Biophys Acad Sci Hung 12:375-388

19. Érdi P, Tóth J (1976) Stochastic reaction kinetics: "nonequilibrium thermodynamics" of the state space? Reac Kinet Catal Lett 4:81-85

20. Tóth J (1978) What is essential to exotic kinetic behaviour? Reac Kinet Catal Lett 9:377-381

21. Tóth J (1979) Gradient systems are cross-catalytic. Reac Kinet Catal Lett 12:253-257

22. Tóth J, Török TL (1980) Poissonian stationary distribution: a degenerate case of stochastic kinetics. Reac Kinet Catal Lett 13:167-171

23. Tóth J (1981) Poissonian stationary distribution in a class of detailed balanced reactions. Reac Kinet Catal Lett 18:169-173

24. Nagy I, Kovács B, Tóth J (2009) Detailed balance in ion channels: application of Feinberg's theorem. Reac Kinet Catal Lett 96:263-267

Publisher's Note Springer Nature remains neutral with regard to jurisdictional claims in published maps and institutional affiliations. 